\title{
PROBLEMATIZATION OF DISTANCE IN THE CONTEXT OF AHMED GÜNER SAYAR'S ECONOMIC THINKING
}

\section{Doç. Dr. Kenan GÖÇER* \\ Doç. Dr. İrfan HAŞLAK * iD}

\begin{abstract}
Ahmet Güner Sayar is known for his works in the field of Turkish economic mentality. He pursued the thought and method of his teacher, Sabri. F. Ülgener in this field to a large extent. He has taken the Ulgerian thought to a new level by subjecting a deeper analysis, for example, by further developing the conceptualisation of 'Turkish custom' and the 'individual' in the context of homo economicus. The debate about the Ottoman people's distance from the tripartite world (matter, environment, and time) continues in Sayar, as Ülgener emphasised. Distance here is defined as remoteness. Both Ülgener and Sayar criticise esoteric Sufism and Malamiyyah in terms of distance. Distance for western people is close enough to know and change the essence of the object. This closeness in the distance constitutes the essence of recreating. Ülgener and Sayar read the contrast between the western and the Ottoman people in terms of distance. The perception of distance is different for both sides and opposed to each other. It is argued in the present work that the distance is not too far from the Ottoman person, but too close to perceive and change the world, which is a tripartite structure. This proximity is, in fact, the absence of distance. Since they saw themselves embedded into universe and nature, the Ottoman people could not see the external nature.
\end{abstract}

Keywords: Ahmet Güner Sayar, Ottoman people, Distance.

JEL Codes: $R 59, H 70, H 11$

\section{AHMET GÜNER SAYAR'IN İKTISAT ZIHHIYYETÇILİ̈̆í BAĞLAMINDA MESAFE MESELESI}

\section{ÖZET}

Kuruluş aşamasındaki Türk iktisat zihniyeti alanında da çalışmaları olan Ahmet Güner Sayar, hocası Sabri F. Ülgener'in bu alandaki düşünce ve yöntemini büyük oranda sürdürmüşsür. Alana kattı̆ $\iota$ yenilik, Ülgener'in vurgularını derinleştirmek, “Türk töresi” kavramsallaştırmasının geliştirilmesi ve

\footnotetext{
* Sakarya Uygulamalı Bilimler Üniversitesi, Uygulamalı Bilimler Fakültesi, Uluslararası Ticaret ve Lojistik Bölümü, Sakarya/ Türkiye. E-mail: kenangocer@ subu.edu.tr

* Sakarya Üniversitesi, Siyasal Bilgiler Fakültesi, Siyaset Bilimi ve Kamu Yönetimi Bölümü, Sakarya/ Türkiye. E-mail: $\underline{\text { haslak@sakarya.edu.tr }}$
}

\section{Makale Geçmiși/Article History}


Yönetim ve Ekonomi Araștirmalarl Dergisi / Journal of Management and Economics Research

Cilt/Volume: 19 Sayl/Issue: 2 Haziran/June 2021 ss. /pp. 405-418

K. Göçer, İ. Haşlak Doi: http://dx.doi.org/10.11611/yead.959681

homo ekonomikus bağlamındaki "birey”dir. Bu anlamda Osmanlı insanının üçlü yapı olan dünyaya (madde, çevre ve zaman) karşı mesafe tartışması, Ülgener'in vurguladiğl şekliyle devam eder. Mesafe burada uzaklık olarak konumlanır. Mesafeli oluş anlamında her ikisinin de eleștirisinden ne batın tasavvuf ne de melâmîlik kurtulabilir. Batı insanı için mesafe ise eşyanın özünü bilip değişstirecek kadar yakındır. Mesafedeki bu yakınlık, yeniden yaratımın özünü oluşturur. Ülgener ve Sayar, Batıl insan ile Osmanlı insanı arasındaki karşıtllğı mesafe üzerinden okur. Mesafenin algılanışı her iki kesim için birbirinden sadece farklı değil, aynı zamanda birbirine karşıttır. Oysa mesafe Osmanlı insanına çok uzak değil, üçlü yapı olan dünyayı algılayıp değiştiremeyecek kadar yakındır. Bu yakınlık bir mesafesizliktir aslında. Kendini dünya/doğa ile birleşik bulduğu için dış doğayı göremez Osmanlı insant.

Anahtar Kelimeler: Ahmet Güner Sayar, Osmanlı insanı, Mesafe.

JEL Kodları: $R 59, H 70, H 11$

\section{INTRODUCTION}

Although Ahmet Güner Sayar is a historian of economic thought, 'he is primarily interested in studies' that combine economic theory with history. Sayar's inquisitive and profound spirit does not allow him to be confined to the subjects which have disciplinary borders. His interest in history and economics exemplify his temporal depth and spatial sphere of influence, respectively. With the spirit that stems from his passion, Sayar conducted research in the history of culture and Turkish economic mentality, which function as the frontier of his main interest, namely the history of economic thought.

The curiosity in question constantly makes him undertake new missions. It is the task of clarifying the controversial points inherited from the Ottoman's intellectual and mental legacy. Each enlightened point is a work that only he can do or he is called to fulfil. However, the work that Sayar carried out turned a passion for him. Therefore, what he does becomes a passion for him, meaning more than work. In this sense, Sayar's ongoing passion in question can actually be seen as a distance closing work. The question of which distance is, in fact, the subject of this article. However, this will be addressed as a matter of economic mentality, one of Sayar's interests.

It is generally accepted that studies on economic mentality in Turkey are insufficient. .Studies to overcome this deficiency are more common in its close neighbouring disciplines, sociology, cultural studies, history, literature, and to a lesser extent, political science, rather than in the field of economics. Although thought is employed synonymously with ideology and idea, it is possible to argue that mentality has expanded its field of existence in the form of 'economic mentality' as conceptualised by Sabri F. Ülgener.

Two people draw attention wherever the concept of "economic mentality" is referred to in Turkey. If the first of these is Ülgener, the other will undoubtedly be Ahmet Güner Sayar. Therefore, it is better to begin with, Ülgener's approach to economic mentality. 
Yönetim ve Ekonomi Araștirmalarl Dergisi / Journal of Management and Economics Research

Cilt/Volume: 19 Sayl/Issue: 2 Haziran/June 2021 ss. /pp. 405-418

K. Göçer, İ. Haşlak Doi: http://dx.doi.org/10.11611/yead.959681

\section{2. ÜLGENER'S APPROACH TO ECONOMIC MENTALITY}

The most substantial opposition to the approach of Karl Marx, one of the dominant discourses in the 19the century social sciences with its assertion that the infrastructure (economy) determines the superstructure (culture, etc.) in the conceptualisation of infrastructure-superstructure, came from Max Weber. Both Weber and Sombart argued that culture (Protestantism, capitalist mentality, Judaism) rather than the economy is the determinant of history.

Ülgener chose to employ the German Historical School's semantic/hermeneutical method against the economy-based determination of Marx on the one hand and the positivist line of Emile DurkheimZiya Gökalp on the other. He used the concept of economic mentality to discuss the Ottomans' failure to realise the industrial revolution. Ülgener, like Sombart and Weber, endeavoured to comprehend the interaction between economic mentality and religion. He did not think that religion was the only and most influential institution in the economic mentality.

Having the idea that mentality would not easily change from today to tomorrow (longue duree), he considered the "ideal type" as the only way to understand the period (Ülgener, 1984: 6). He had the idea that mentality should be taken into account in addition to material factors in the studies of economic history (Ülgener, [1951] 1991: 13; 1984: 5). He emphasized that studies of economic mentality should be seen as a supporting and supplementary element to the studies of economic history.

Ülgener argues that mentality research can be summarised around two points:

1. It is essential to draw a comprehensive framework of economic ethics and mentality of the period in question. This framework should be drawn in the context of human behaviour and World views, accepted as the 'ideal type' of the period and the subject of economics.

Thus, after constructing a general outline of the period retroactive:

2. The effects of different elements (religion, sect, religious order, etc.) in the emergence of the mentality in question over the centuries are demonstrated. In doing so, the stages the mentality went through during its emergence and spread, what it was affected by and what factors it fought with until it is settled are examined ((1991: 13; [1981] 2015: 5).

As the number of studies prioritizing culture against Marxism increased in the twentieth century, Ülgener also did not deviate much from this path. Economic activity is the sum of the multifaceted relations between human and matter, environment and time (2015:29) in need satisfaction or the human's attitude and distance to three mentioned attributes.

Within this context, Ülgener has the view that western people, as the industrial revolution illustrates, closed the distance against matter, environment, and time (all three can be called the world). $\mathrm{He}$, on the contrary, argues that this distance was noticeably high for the Ottoman people (2015: 32 and 96-98). The distance to the World is derived from a "non-materialised world view" (1991: 53). Tradition 
and esoteric Sufism played a dominant role in the formation of the non-materialised worldview (Ülgener, 2015: 28-52; Sayar, 2001: 127). However, the only hope to engage and close the distance with the matter was the Malamis. Their commitment to acquiring a profession and working made Malamis seen separately from other Sufi circles. Be that as it may, as the Malamis also adopted the principle of spending and distributing the capital rather than accumulating it and preferred staying away from, and keeping their distance to, the world, they could not serve a function that would open the way to the Ottoman industrial revolution or rationalism (Göçer, 2017a; Ülgener, 2015: 103-118).

What did Ülgener, who, in Sayar's words, 'wanted to grasp the roots of the ottoman legacy of social inertia", understand from mentality? Or what is his definition of mentality? Ülgener provides an answer to this question in his work Hardships Crises and the Politics of Islamic Economy: 'The mentality is the aggregation of ideas that have accumulated over many centuries and are rendered entirely instinctive to the subconscious, independent of the personal desires and wills of certain groups. Economic mentality, thus, easily distinguishes itself from ideas, that is to say from ideologies, behind which greedy interests are mostly hidden' (1984: 9).

Nevertheless, to understand his conceptualisation of economic mentality necessities looking into the 'ethics of economics', which is probably supplementary to that conceptualisation. Redefining both concepts in the context of their relationships with each other will make it possible for us to understand them more accurately and clearly. While ethics of economics refers to "the total expression of the norms and rules which are to be followed", the economic mentality is "the sum of values and beliefs that a person pursues in his real behaviour'.

By giving the examples of the mosque and the market (bazaar) to the ethics of economy and economic mentality, respectively, Ahmet Güner Sayar provides a solution to the increasingly complex definition problem, thereby making the matter clear. Sayar, indeed, wittingly or unwittingly, endeavour to get to know the society by employing mosque-bazaar example or makes an effort to close the distance of society to abstract thinking. In this sense, the mosque speaks in the 'have to,' mode, while the bazaar says 'is', and puts its judgment into practice.

What is Sayar's contribution to the Turkish economic mentality, and how is distance handled in his contribution?

\section{ECONOMIC MENTALITY IN THE THOUGHT OF AHMET GÜNER SAYAR}

Sayar, in almost all his works, except for those in economic theory, albeit large and small, pursues the following question, which he asks himself and the intellectual and enlightened public opinion in Turkey: 'Why did the capitalisation process failed to strike its spark in the Ottoman country in these historical periods' (Sayar, 2000: 128). Sayar's question is almost identical to the set of questions and concerns his mentor Ülgener put forward for the Turkish economic mentality. Their answers are, in 
fact, nearly overlapped. Be that as it may, Sayar's answers exhibit a difference or richness in deepening Ülgener's findings.

All the phenomena such as esoteric Sufism, Malamiyyah, ahi-order, distance stance towards the world (matter, environment and time), irrational structure, closure to innovation, master-lord consciousness, tradition, liberal individualism (individual), competitiveness and solidarity, price- fixing and free market that Ülgener dealt with in the context of his economic mentality, have been rehandled in depth by Sayar in the light of his cultural and literary accumulation with an idiosyncratic and unique style.

Sayar restated the phenomena discussed by Ülgener, namely master-agha consciousness and tradition under the heading of Turkish custom as he conceptualised (Sayar, 2001: 31). He emphasises within this context, that Turkish custom conflict with Islamic ethics (Sayar, 2001: 117). What Sayar means by Turkish custom for which he does not elaborate much but has the opinion that research should be conducted on is eating, offering, looting, and plundering (Sayar, 2001: 50-51). However, he does not designate the Ottoman economic order as a plundering regime (Sayar, 2001: 51).

The phenomenon expressed as eating, offering, plundering, and looting in Turkish, has been conceptualised as potlatch (potlatch, gift, donation) in the international literature. The concept of potlatch presented to the academic community in 1925 by Marcel Mauss was first framed in his book 'An Essay on Donation' (Mauss, [1925] 2006). Potlach is a lifestyle that prevailed in pre-monotheistic societies (Adanır, 2010: 33). Nevertheless, potlatch continued to exist in some societies after monotheistic religions. Social and political determine the economy in a potlatch-based environment.

While setting the framework of the Turkish custom, Sayar seems to have a different view from the debate conducted around the potlatch in Turkey and the world. Except for Marxism, almost the most substantial debate in many cultural study areas such as philosophy, sociology, art, literature, and economics in the world has been carried out over the potlatch (gift, donation, present). If Sayar had taken part in the discussion in question, he would have deepened the concept of 'Turkish custom,' which he left at the introductory level. His portrayal of Islamic ethics and the Turkish custom as opposed to each other is challenging. The main emphasis of Islam is, in fact, on giving. In the first verse of the Qur'an (Igra), the expressions of the Lord being generous, the Qur'an being generous, Meccas being glorious, the Prophet being generous, all remind us of giving, even giving the most (offering) (Göçer, 2017b: 72-77). Oğuz Adanır approaches the Turkish custom or the potlatch in his work titled A New Look at the Old World (2010) through J.Baudrillard, N.Berkes, M.Mauss, and S.Ülgener in the Ottoman context with in-depth and provocative questions. Although it is not a study dealing with the pre-Ottoman period, the thesis in it can be easily extendable backwards.as the characteristics (mentality) of the society do not change from today to tomorrow. Adanır claims that as long as external conquests continued, the 
Ottoman gave to his society. According to him, When external conquests stopped, the Ottoman switched to a simulation of giving (taking by pretending to give) by turning to internal conquest (confiscation).

Sayar's frequent reference to the Turkish custom can be attributed to his view that the effect of the religion (esoteric Sufism) on Ottoman society was exaggerated. Two factors seem to have affected this view: On the one hand, a world in which sociologists such as Weber and Sombart dominated is left behind, and on the other hand, philosophy, psychology, art and other cultural studies are built on language.

Apart from Turkish custom, another point that Sayar emphasises more than Ülgener is the absence of 'economic individual'. As one of the epitomes of rationality, the individual did not appear in the Ottoman society. Esoteric Sufism and Turkish custom are two main factors responsible for such a failure These two characteristics are held responsible for almost all the negativities, such as the inability to realise the accumulation of capital and carry out the industrial revolution, to fail to contact with the matter and to be distant from the world in the Ottomans. He tries to prove this by utilising the works of leading Sufis. When the final point to be reached is accepted as capitalism, the industrial revolution, and rationalism-individual, all reasons put forward by Sayar take a convincing form.

The present work intends to focus more on the emphasis on distance and its nature in Sayar in the sense of economic mentality rather than his contributions to the Turkish economic mentality.

\section{DISTANCE IN SAYAR}

Ülgener was the first to address distance in the context of Economics mentality. He suggested looking at the distance from matter (object), environment, and time, a set of tripartite concept developed to understand economic ethics and society's mentality (2015: 67, 96-98). For Ülgener, the extent of the distance is tantamount to a life characterised with disinterestedness, indiscrimination, monotony and imitation-repetition. A distant attitude, for example, towards an object and the absence of the will to find the ore in the object is evaluated as avoiding contact with the object. That leads to outcomes such as not recognizing the object and not being able to benefit from it sufficiently and adequately. He also refers to the distant stance towards the object as disinterest in some cases. The distance in question may sometimes originate from 'the prohibition of new inventions.' The stance against the new, or even banning it, can be expressed as regulating life in all its aspects.

Sayar considerably broadens the utilisation of the concept of distance that he inherited from Ülgener. Avoiding contact with the object is the result of being uninterested in its essence. The reason for this disinterest, as emphasized above, is the effort to fix the whole life on immutability. Everything has a rule, and no one can break it. Rhythm in the poem, the number and size of the shops in the bazaar, price of the goods(price-fixing), colour, and style of turban-fez to be worn on the head were all determined. There seems to be almost nothing unarranged in society. Life is orderly in all its aspects. Avoiding breaking the rhythm means complying with the social order and living well. In this case, 
fighting with the object will mean dimming, not enriching life. Are you bringing a new custom to the old village! Don't you dare!

According to Sayar, it is without any doubt that 'uneconomic (one) matter and perception of the world' would develop when "avoiding coming to terms with the economic matter" in the Ottoman cultural climate. In that case, 'we see that the economic behaviour of the Ottoman people was established somewhere outside of Islamic economic ethics... This is above all a conflict between ethics (norm) and mentality (reality)' (2001: 31). For Sayar, the reason for this is the custom and esoteric Sufism in the sense of Asian Turkish custom. It is not surprising that such a 'perception of economic matter failed to bring about accumulation', which lacks curiosity, research and contact with the object. He underlines the point that the dominant Sufi perception prevented our people from reaching economic matter (2001: $49,120)$.

Nevertheless, he points out that when encountering the object, Malamis 'give up fighting' as their life is based on "sufficient quantity of the goods". Accordingly, he asserts that the "Bayrami Malamiyya, located outside of 'esoteric Sufism', did not allow the emergence of a mathematical typology" (2001: 33). Sayar insists that Malamis also lost their 'fight' regarding closing the distance with the object.

He argues that the 'most serious mistake' of the ottomans was 'their inability to notice scientifically the capacities that exist in the matter' (2001: 54). 'We have always been distant from the matter. Our biggest fault was our stance towards the matter. We could not touch our bodies. NonMuslims conducted the profession of medicine'. 'We did not know from what diseases died our people. There was no questioning. In the course of 574 years from the time of Osman Ghazi to Abdülhamid II, there was no evolution in land and the plough. Therefore, our perspective towards the matter began to change with the Republic.' (2001: 55-56).

Everything was seen as universal or as nature to the extent that matter was not touched. Parallel to this, the individual could not emerge. Just as the matter could not be approached separately from the nature, the individual could not be seen as separate from society, generality and universality. As in Yunus Emre's expression "we did the market affairs on a lump", life or work was not dealt with in detail. Three down five up (more or less), lump sum became the way of doing business. There was no dissociation in mind regarding this. Because 'something, first, happens in the minds, you set off from there and look at the object' (2001: 126).

While this was the case in the Ottomans, how was the situation regarding the distance in the West? How and why was the distance closing there? Sayar reads the situation of the West (Europe)in terms of (geographic) 'congestion': 'Turks are walking on it; on the other, there is the Atlantic. It is stuck in between. In the meantime, it reasoned the talent [ore, ability] that exists in matter, namely only the scientific knowledge. According to their logic, Europe reaches the existing data in the object and tries to find a way out of it... It begins to question (transform) social superstitions. Furthermore, it dissolves 
Christian superstitions.' (2001: 124-125). Sayar sees the exit or the closing process of the distance to the object, to put it briefly, as follows: External shock $\rightarrow$ compression $\rightarrow$ questioning-criticism $\rightarrow$ disintegration of matter and emergence of the individual.

He thinks that Turkish society cannot close its distance from matter without experiencing an external shock.

\section{A BRIEF DISCUSSION ON DISTANCE}

Distance is defined as the spatial difference between two things. However, when delve further into the issue, we can notice temporal, formal, relational and hierarchical (vertical) distances. The distance discussed in the sections above is largely an example of the relational distance. In the Ottoman specific, both Ülgener and Sayar argue that there is a great distance in our interest towards the matter and the environment. Ottomans' relationship with time concerning distance emphasises that they have the consciousness of near-time and a vision of no more than a year.

In the international literature of the Social Sciences, distance conceptualization occurs in the form of social distance or power distance. They both function almost closely. Karl Mannheim argues that superiority and fear create social distance (Mannheim, 2017: 276). Another example of social distance is the vertical distance between hierarchically unequal ones (2017: 277). When looked at such issues in terms of democratization, which are the 'duty of the cultural sociology', a 'reduction of the vertical distance, abolition of the established distance' will mean reducing the distance between the ruler and the ruled (2017: 278). The army and bureaucracy are the most concrete indicators of distance building.

The distance can also be seen in the sense of self-creation. For example, when we see our 'self' as an 'other', we begin to get to know ourselves better. It is also unlikely that we will 'see' the objects of the external world without actually forming the self or creating an image of the self about ourselves. Otherwise, everything is experienced in nature, in its naturalness, but not seen. For example, before we were born, we live with our mother in her nature/naturalness, but we do not see her. To be able to see necessities getting out of or distancing from that nature. Unless a person leaves the nature (womb or social structure) where he was before, he will not be able to see that structure, nor will he be able to see things/objects in that structure/nature. M.Bilgin Saydam discusses this point in detail in Ara'fdalıklar (2017). However, issues such as to what degree one can get out of nature, the possibility to get out fully, if one can see without fully leaving, or to what extent one 'sees' are discussed.

The ability to look at yourself from the outside requires some abstraction. Abstraction requires abandoning or pretending to abandon concreteness / mother-nature / material / matter. From Socrates to Indian thought and Islam, and from Islam to Yunus, many exceptional schools of thoughts and thinkers emphasized 'knowing yourself!'. The other aspect of knowing oneself is to accept the existence of the 'other'. Our encounter with the "other", the 'wild' in its uniqueness, will lead us from the collective 
structure of 'we-ness' to the uniqueness of the 'self' (individual). One will be able to exist himself to the extent that he can meet the other (May, 2018: 96).

The chance of a social member who cannot take himself out of the collective structure/community to become an 'individual' will diminish to the extent that he remains in the community/society. The person who cannot create a distance from society will not see an object (object, matter) in the social structure/nature (Berger, 2016). As Sayar put it, seeing here is characterised with routine and instrumental use, lacking to observe the capacity in matter. Within this context, Sayar seems to have inherited the view from Ülgener that the Ottoman people were distant-perhaps extreme- from matter/object.

Keeping a little distant from the approach of both Ülgener and Sayar, supporting each other in an interrupted way, will bring about a different picture. The object too far away to be penetrated is a possibility, as well as its inseparability; that is, the absence of distance in mother/nature is a possibility. In this case, it seems more reasonable to go to the starting point of the chain, that is, to the state of the absence of distance. Because seeing does not exist in both possibilities. Since matter does not arise / dissociate from nature, it is an extension/part/thing of nature/mother that compliments it. It is not a thing in itself but an extension of something. What is seen, in this case, is mother/nature.

When we say that the Ottoman people cannot touch the object and are too distant from it, we actually admit that they are too far away to be interested in it. If so, should not we accept that there was a stage before locating the object away or at a certain distance? That is to say that we have to implicitly admit that his distance from the object was close before; he sees it, touches it, realises the capacity in it, and thinks it over. was there such a period that existed? If it happened, when did it happen, and why did it not continue? If the answers to these questions are negative, we can assume that the long-distance also never occurred.

The absence of distance arises two possibilities: Long -distance and distancelessness. We have already mentioned that distancelessness is a loss of vision as well as long-distance. In particular, in the Ottoman case, we endeavour to imply that one has no chance or attempt to look at the natural environment in which they are present or externally looking at mother from the womb. we try to point out clearly that there is not a long-distance; on the contrary, distance is absent.

We agree with Sayar's illuminating observations regarding the closing of the distance in the west. Without any doubt, it will be further elaborated if the findings in question are dwelled on a little more. If we say it through Sayar's point of view, what we see in the closing of distance is the appearance of the thing/object to the realm of existence and even its creation. It would be more accurate to show this in a table. The following table depicts the proposed conceptualisation of the matter's distancing throughout history: 
Yönetim ve Ekonomi Araștirmalarl Dergisi / Journal of Management and Economics Research

Cilt/Volume: 19 Sayl/Issue: 2 Haziran/June 2021 ss. /pp. 405-418

K. Göçer, İ. Haşlak Doi: http://dx.doi.org/10.11611/yead.959681

Table 1: Matter's Distancing throughout History

\begin{tabular}{|l|l|l|}
\hline \multicolumn{1}{|c|}{ 1-Absence of distance } & \multicolumn{1}{c|}{ 2-Close distance $\rightarrow$} & 3- Long distance \\
\hline No sight & Having sight & No sight \\
\hline Within nature/mother & Encounter with other / creation & $\begin{array}{l}\text { Too far to see (Located at too far } \\
\text { too see) }\end{array}$ \\
\hline
\end{tabular}

Ottoman People's distancing to object/matter mentioned in Ülgener and Sayar is formulated as the long distance, the third stage. We propose distance closing in the West to the object as the close distance (second stage) or the distance formation. It is worth explaining why we express it as the distance formation. First of all, there must be a certain distance to see. Object in nature/mother is too close to the eye to see. When the mother takes her child out of the absence of the distance (mother's womb) to a certain distance (birth, out of nature), she meets, him/her and seeing begins at this moment. We refer to the stage the west began to see as the second stage at which distance formation occurred, whereas Ülgener and Sayar call it as the stage of distance closing with the object. If the West reached this stage, there must be a previous one. If the Ottomans and the Turks could not get to this stage, the current position in which they were should be the previous position/stage of the West. In that case, where is this stage? This stage can be described as the state of absence of distance, unrecognizability, and, in terms of its everyday place and functioning, inescapable nature of the object beyond conventional existence. Naturally, this stage is the one before the stage where the West is. The inability to go beyond the conventional existence regarding the everyday place and functioning of the object can be called a state of nature or being in the mother's womb. There is, of course, development in the mother's womb, but it does not have an identity, but it will. It may at least be within a certain period. What is the length of this period? As long as nutrition and life safety are ensured, it is highly likely to exist and acquire an identity.

The formation of distance in the West may have something to do with fear. However, it is not the only factor leading to this outcome. What might these be? Looking at the issue over distance again will be helpful in our analysis, and following this line of thinking will enable us to see certain clues. We touched on these issues here at the assertion level, which needs to be addressed in detail. There are historical roots of the psychological, sociological, artistic, literary, religious, political, philosophical, and economic aspects of the issue that go beyond the limits of this article.

The emergence of the accounting system, for example, can be accounted for in this context. There was, of course, an accounting system (one-way) before. An accounting system (two-way) on which the West based in the $13^{\text {th }}$ and 14 th centuries, unlike the previous one, became independent from the person who kept the account (distancing), circumvent being regarded only a reminder number of clusters, and the account kept became a commodity that another could monitor. The separation of the account holder and the account stems from the emergence, distancing a self-explanatory accounting aspect at every place and time. 
Previously, accounting seemed complex, inexplicable to someone other than the person who held that accounting. The accounting record and the accountant was an inseparable (absence of distance) integrity (nature). This negatively affected partnerships in the Islamic or the Ottoman World. The life of partnerships was limited to the life of those who established the partnership. Partnerships were often formed for a single caravan expedition, and the accounting records were found incomprehensible even to founders' children. The term grocery ledger, a one-way recording system, is often used to imply the account's complexity and its inextricability.

The meaning of the phrase in question is that the account will only avail if the person who keeps the record has a good memory and can remember it, and it hasn't got any meaning for the third parties. The absence of the two-way registration (accounting) system or the lack of standardised accounting also caused the partnerships to be short-lived, leading to the failure in capital accumulation. It all shows the nonexistence of a legal entity in the Ottomans until the 20th century (Kuran, 2018: 128-131, 169).

We can also see a legal entity as a literary type of fictional personality. The accounting, a standard recording system (independent of the person, distant from the person), the rise of the legal entity and the novel as a company partnership or Corporation and a literature type respectively, were a chain of events in the West that almost followed and nurtured each other, progressed cumulatively and enabled accumulation in all aspects.

In contrast to Ülgener and Sayar's discourse related to the 'distance closing' expressed above, we offered the concept of 'distance formation' following the table's historical course. However, this is not the case in the novel. What makes the emergence of the novel as a new literature type is the attempt to close the distance between 'authentic language' used by the people in daily life and the 'tradition of ornamental language' (Watt, 2018:31) used in romances and tragedies during Ancient Greece, Rome and the Classical Period. The emergence of the novel as a type is, in a way, the attempt to re-close the distance, created by grandiloquent or ornate style. The novel was embraced and developed to the extent that it came close to the daily language in terms of language and style. What Ülgener and Sayar call 'distance closing' is valid only in the example of the emergence of the novel.

This crucial issue, which Ülgener and Sayar draw attention to, should be addressed in an even broader framework. It is worth reminding that this factual and partly conceptual debate opened up Ülgener, and Sayar's school was tackled in a little more detail in the context of work mentality (Göçer, 2019).

\section{CONCLUSION}

In his work on the Turkish economic mentality, Ahmet Güner Sayar followed in the footsteps of his teacher Sabri F.Ülgener and employed his method. The method used by the Ottoman people to regulate their distance to the world is the relationship they established with the world, which means the tripartite structure, which stands for matter, environment and time. Similar to Ülgener, Sayar also points out that 
the Ottoman people could not close their distance in this relationship. As the distance could not be closed within the defined tripartite structure, the Ottomans could not realize accumulation, failed to bring about the industrial revolution and did not create the individual.

However, there are two reasons for this when distanced emergence is accepted. Firstly, as the world that has to be seen is not separate from the person, there is no distance between the person and the world. In this case, the world is not visible to the person. It is used and left behind. In the second case, the world is too far to see Both Ülgener and Sayar attempted to deal with the distance in the second situation, but they never touched upon as to why Ottoman people opted for distancing in its first meaning, as expressed above. In order to reach a distant position in the second situation, western people must pass beyond the stage of distance closing from the world.

Our study shows through the spatial map (table I) that the thesis Sayar put forward as his thesis on being distant is, in fact, a state of the absence of distance. When it is said that the Ottomans were distant from the tripartite structure, it is accepted that the Ottomans would also pursue the stages of the west. In other words, similar to the West, its distance was close to the tripartite structure or the World, but later, the distance gradually grew. But nothing like this happened in reality. Therefore, Sayar's statement should be revised. The demand for its revision constitutes the purpose of this article.

In our opinion, revision can be expressed in the light of table I as such: First, distance is absent. For example, there is no distance between the pupil and the person. Therefore, we cannot see our eyes. As we cannot see it, we cannot research it. In the second stage, the object is within the range of being seen. As it is seen, it can be examined. The west is in this state. In the third stage, the world, which is a tripartite structure, is at a distance that cannot be seen, touched, and searched. According to Ülgener and Sayar, the distance of the ottoman people with the tripartite structure is in that last position. If this was the case, the Ottoman people earlier must have seen the second stage of the tripartite structure. As there is no such historical period, the relationship of the Ottoman people with the tripartite structure can only be in the first stage. So, just as they pointed out, at this stage, they only used the world.

Starting with Ülgener and continuing with Sayar, the debate about the Ottoman people's distancing from the world was thus taken one step further.

\section{REFERENCES}

Adanır, O. (2010), Eski Dünyaya Yeni Bir Bakış, Doğu Batı Yayınları: Ankara.

Berger, J. (2016), Görme Biçimleri, çeviren Yurdanur Salman, Metis Yayınları: İstanbul.

Göçer, K. (2017a), "Melâmîliğin Türklerin İktisat Zihniyeti Üzerindeki Uzun Dönem Etkisi”, Türk Dünyası Araştırmaları, C.115, Sayı 227, ss.115-132, 2017.

Göçer, K. (2017b), “Kuran’daki Arz ve Dünya Kavramlarının Osmanlı İktisat Zihniyeti Üzerine Etkisi”, 15. Uluslararası Türk Dünyası Sosyal Bilimler Kongresi içinde, ss.70-82, Moldova. 
Göçer, K. (2019), Türkün İş Zihniyeti, Nobel Yayınları: Ankara.

Kuran, T. (2012) Yollar Ayrllırken, çeviren Nurettin Elhüseyni, Yapı Kredi Yayınları: İstanbul.

Mannheim, K. (2017), Kültür Sosyolojisi, çeviren Mustafa Yalçınkaya, Pinhan Yayıncılık: İstanbul.

Mauss, M. (2006), Sosyoloji ve Antropoloji, çeviren Özcan Doğan, Doğu Batı Yayınları: Ankara.

May, R. (2018), Yaratma Cesareti, çeviren Alper Oysal, Metis Yayınları: İstanbul.

Sayar, A. G. (2000), Osmanlı İktisat Düşüncesinin Çağdaşlaşması, Ötüken Neşriyat: İstanbul.

Sayar, A. G. (2001), Osmanlı'dan 21. Yüzyıla, Ötüken Neşriyat: İstanbul.

Saydam, M. B. (2017), Ara 'f'dalık-lar, İstanbul Bilgi Üniversitesi Yayınları: İstanbul.

Ülgener, S. F. ([1951] 1991), Ikktisadi Çözülmenin Ahlak ve Zihniyet Dünyası, Der Yayınları: İstanbul.

Ülgener, S. F. ([1981] 2015), Zihniyet ve Din, Derin Yayınları: İstanbul.

Ülgener, S. F. (1984), Darlık Buhranları ve İslâm İktisat Siyaseti, Mayaş Yayınları: İstanbul.

Watt, I. (2018), Romanın Yükselişi, çeviren Ferit Burak Aydar, Metis Yayınları: İstanbul.

\begin{tabular}{|c|c|c|}
\hline $\begin{array}{c}\text { KATKI ORANI / } \\
\text { CONTRIBUTION RATE }\end{array}$ & $\begin{array}{c}\text { AÇIKLAMA / } \\
\text { EXPLANATION }\end{array}$ & $\begin{array}{c}\text { KATKIDA BULUNANLAR / } \\
\text { CONTRIBUTORS }\end{array}$ \\
\hline $\begin{array}{c}\text { Fikir veya Kavram / Idea } \\
\text { or Notion }\end{array}$ & $\begin{array}{l}\text { Araştırma hipotezini veya } \\
\text { fikrini oluşturmak / Form the } \\
\text { research hypothesis or idea }\end{array}$ & $\begin{array}{l}\text { Doç. Dr. Kenan GÖÇER } \\
\text { Doç. Dr. İrfan HAŞLAK }\end{array}$ \\
\hline Tasarım / Design & $\begin{array}{l}\text { Yöntemi, ölçeği ve deseni } \\
\text { tasarlamak / Designing } \\
\text { method, scale and pattern }\end{array}$ & $\begin{array}{l}\text { Doç. Dr. Kenan GÖÇER } \\
\text { Doç. Dr. İrfan HAŞLAK }\end{array}$ \\
\hline $\begin{array}{c}\text { Veri Toplama ve İşleme / } \\
\text { Data Collecting and } \\
\text { Processing }\end{array}$ & $\begin{array}{c}\text { Verileri toplamak, } \\
\text { düzenlenmek ve raporlamak / } \\
\text { Collecting, organizing and } \\
\text { reporting data }\end{array}$ & $\begin{array}{l}\text { Doç. Dr. Kenan GÖÇER } \\
\text { Doç. Dr. İran HAŞLAK }\end{array}$ \\
\hline $\begin{array}{l}\text { Tartışma ve Yorum / } \\
\text { Discussion and } \\
\text { Interpretation }\end{array}$ & $\begin{array}{l}\text { Bulguların } \\
\text { değerlendirilmesinde ve } \\
\text { sonuçlandırılmasında } \\
\text { sorumluluk almak / Taking } \\
\text { responsibility in evaluating } \\
\text { and finalizing the findings }\end{array}$ & $\begin{array}{l}\text { Doç. Dr. Kenan GÖÇER } \\
\text { Doç. Dr. İran HAŞLAK }\end{array}$ \\
\hline $\begin{array}{l}\text { Literatür Taramas1 / } \\
\text { Literature Review }\end{array}$ & $\begin{array}{c}\text { Çalışma için gerekli literatürü } \\
\text { taramak / Review the } \\
\text { literature required for the } \\
\text { study }\end{array}$ & $\begin{array}{l}\text { Doç. Dr. Kenan GÖÇER } \\
\text { Doç. Dr. İran HAŞLAK }\end{array}$ \\
\hline
\end{tabular}




\section{Hakem Değerlendirmesi: Dış bağımsız.}

Çıkar Çatışması: Yazarlar çıkar çatışması bildirmemiştir.

Finansal Destek: Yazarlar bu çalışma için finansal destek almadığını beyan etmiştir.

\section{Teşekkür: -}

Peer-review: Externally peer-reviewed.

Conflict of Interest: The authors have no conflict of interest to declare.

Grant Support: The authors declared that this study has received no financial support. 